\title{
Effect of Protein Composition on the Cheese-Making Properties of Milk from Individual Dairy Cows
}

\author{
A. Wedholm, ${ }^{* 1}$ L. B. Larsen, $†$ H. Lindmark-Månsson,‡ A. H. Karlsson,§ and A. Andrén* \\ *Department of Food Science, Swedish University of Agricultural Sciences, SE-750 07 Uppsala, Sweden \\ †Department of Food Science, Danish Institute of Agricultural Sciences, Research Centre Foulum, DK-8830 Tjele, Denmark \\ $\ddagger$ Swedish Dairy Association, SE-223 63 Lund, Sweden \\ $\S$ Department of Food Science, The Royal Veterinary and Agricultural University (KVL), DK-1958 Fredriksberg C, Denmark
}

\begin{abstract}
The objective of this study was to evaluate the effect of variations in milk protein composition on milk clotting properties and cheese yield. Milk was collected from 134 dairy cows of Swedish Red and White, Swedish Holstein, and Danish Holstein-Friesian breed at 3 sampling occasions. Concentrations of $\alpha_{\mathrm{S}^{-}}, \beta$-, and $\kappa$-casein (CN), $\alpha$-lactalbumin, and $\beta$-lactoglobulin (LG) A and B were determined by reversed phase liquid chromatography. Cows of Swedish breeds were genotyped for genetic variants of $\beta$ - and $\kappa$-CN. Model cheeses were produced from individual skimmed milk samples and the milk clotting properties were evaluated. More than $30 \%$ of the samples were poorly coagulating or noncoagulating, resulting in weak or no coagulum, respectively. Poorly and noncoagulating samples were associated with a low concentration of $\kappa$-CN and a low proportion of $\kappa$ - $\mathrm{CN}$ in relation to total $\mathrm{CN}$ analyzed. Furthermore, the $\kappa$-CN concentration was higher in milk from cows with the $\mathrm{AB}$ genotype than the AA genotype of $\kappa$-CN. The concentrations of $\alpha_{\mathrm{S1}^{-}}, \beta-$, and $\kappa$-CN and of $\beta$-LG B were found to be significant for the cheese yield, expressed as grams of cheese per one hundred grams of milk. The ratio of $\mathrm{CN}$ to total protein analyzed and the $\beta$-LG B concentration positively affected cheese yield, expressed as grams of dry cheese solids per one hundred grams of milk protein, whereas $\beta$-LG A had a negative effect. Cheesemaking properties could be improved by selecting milk with high concentrations of $\alpha_{\mathrm{S}^{-}}, \beta$-, and $\kappa$-CN, with high $\kappa$-CN in relation to total $\mathrm{CN}$ and milk that contains $\beta$-LG B.
\end{abstract}

Key words: cheese yield, milk protein composition, milk clotting properties, poorly coagulating milk

\section{INTRODUCTION}

In many milk-producing countries, a large fraction of the milk produced is used for cheese making. In the

Received January 13, 2006.

Accepted March 12, 2006.

${ }^{1}$ Corresponding author: Anna.Wedholm@lmv.slu.se
Scandinavian countries, about one-third of the total volume is used for this purpose. The quality and amount of cheese obtained, not only per volume of milk but also per gram of protein in cheese milk, is important for the economic outcome of the dairy industry. The milk clotting properties are important both with regard to quality and yield of cheese. It has been suggested that a firmer curd at cutting is positively correlated to yield of cheese (Aleandri et al., 1989; Martin et al., 1997). Johnson et al. (2001) showed that a firmer curd at cutting resulted in reduced-fat Cheddar cheeses with higher moisture content. However, the milk clotting properties are variable, and factors influencing these properties include the concentrations of total $\mathrm{CN}$ and calcium (Storry et al., 1983), pH (Najera et al., 2003), genetic polymorphism of milk proteins (Schaar et al., 1985; Mayer et al., 1997; Ikonen et al., 1999a), stage of lactation (Okigbo et al., 1985c; Ostersen et al., 1997), season (O'Brien et al., 1999), and feeding (Verdier-Metz et al., 1998). Differences in milk clotting properties between different breeds have been previously studied in the United Kingdom (Verdier-Metz et al., 1998), France (Macheboeuf et al., 1993), Italy (Chiofalo et al., 2000), Ireland (Auldist et al., 2002), and New Zealand (Auldist et al., 2004).

Genetic polymorphism of milk proteins has been associated with composition, production traits, and technological properties of milk. Concentration of $\beta$-LG is higher in milk with the AA genotype than with $\mathrm{AB}$ or BB (McLean et al., 1984; Ng-Kwai-Hang et al., 1987; Graml et al., 1989), which results in a lower CN number in AA milk (Lunden et al., 1997; Schaar, 1984; van den Berg et al., 1992). Several workers have reported significantly higher concentrations of $\kappa$-CN in milk with the B allele (McLean et al., 1984; van den Berg et al., 1992; Bobe et al., 1999). The B allele of $\kappa$-CN has also been associated with improved milk clotting properties (Schaar, 1984) and a higher cheese yield (Schaar et al., 1985), whereas the $\mathrm{E}$ allele has been related to unfavorable milk clotting properties (Ikonen et al., 1999a; Caroli et al., 2000). Many studies have been carried out on the effects of genetic polymorphism on 
milk clotting properties and cheese yield (Ng-KwaiHang, 1998), whereas studies evaluating the actual milk protein composition in relation to cheese-making properties of individual milk samples are less frequent (Auldist et al., 2004). The CN to total protein ratio has decreased in Swedish bulk milk during the last decades, making it less suitable for cheese making (LindmarkMånsson et al., 2003). Deteriorating trends like this may also occur in other countries, and therefore, it is important to identify suitable quality markers for cheese milk. In Sweden, milk is currently graded according to concentrations of total protein and milk fat. It could be an economical advantage to the dairy industry if a specific marker could be used to identify milk suitable for cheese making; that is, good milk clotting properties and high cheese yield. The object of this study was thus to evaluate the effect of protein composition on milk clotting properties and cheese yield from milk of individual cows.

\section{MATERIALS AND METHODS}

\section{Milk Collection and Experimental Design}

Evening whole milk samples (approximately $10 \mathrm{~L}$ ) from 16 Swedish Red and White (SRB), 15 Swedish Holstein (SLB), and 14 Danish Holstein-Friesian (SDM) cows were collected in September 2003. Milk from SRB and SLB were collected at the experimental dairy herd at Jälla (Swedish University of Agricultural Sciences) and milk from SDM was collected at the Research Centre Foulum (Danish Institute of Agricultural Sciences). A second sampling from 22 SRB, 8 SLB, and 15 SDM took place in January 2004, and the last sampling from an additional 20 SRB, 9 SLB, and 15 SDM was carried out in May 2004. A total of 134 cows was thus included in the study and no cow was sampled twice. Feeding and management was carried out according to standard practices in the respective countries and the cows were held indoors on the 3 sampling occasions. All cows included in the study were healthy and milked twice a day. The cows were grouped into 4 classes according to stage of lactation: early (wk 6 to $15 ; \mathrm{n}=27$ ), mid (wk 16 to $30 ; \mathrm{n}=69$ ), late (wk 31 to $45 ; \mathrm{n}=30$ ), and very late (wk 46 or later; $\mathrm{n}=8$ ). All breeds were represented within each stage of lactation class. The cows were also grouped into 4 classes according to lactation number: first lactation $(1 ; \mathrm{n}=50)$, second lactation $(2 ; \mathrm{n}=42)$, third lactation $(3 ; \mathrm{n}=22)$, and fourth or more lactation $(4 ; \mathrm{n}=20)$. All breeds were represented within each lactation number class.

\section{Milk Composition}

Samples of fresh milk were analyzed for concentration of milk fat, lactose, urea, and $\mathrm{pH}$ by a Milkoscan
FT 6000 (A/S N., Foss Electric, Hillerød, Denmark) and for somatic cells using a Fossomatic 5000 (A/S N., Foss Electric) at Steins Laboratory (Holstebro, Denmark). Calcium content was determined using atom absorption spectrophotometry after drying to ash at $525^{\circ} \mathrm{C}$ for 6 $\mathrm{h}$, followed by dissolving in acid and dilution in lanthanchloride solution. Concentrations of major milk proteins were determined using the reversed phase liquid chromatography (RP-HPLC) method modified by Wedholm et al. (2006) according to Bordin et al. (2001). No measurement was made for $\alpha_{\mathrm{S} 2}-\mathrm{CN}$. Concentration of total protein analyzed was defined as the sum of the concentrations of $\alpha_{\mathrm{S} 1}-\mathrm{CN}, \beta$-CN, $\kappa$-CN, $\beta$-LG A, $\beta$-LG $\mathrm{B}$, and $\alpha$-LA. Concentration of total $\mathrm{CN}$ analyzed comprised the sum of the concentrations of $\alpha_{\mathrm{S} 1}-\mathrm{CN}, \beta-\mathrm{CN}$, and $\kappa-\mathrm{CN}$, and concentration of total whey protein analyzed comprised the sum of the concentrations of $\beta$-LG $\mathrm{A}, \beta$-LG B, and $\alpha$-LA. Proteolysis in individual pasteurized skimmed milk samples were determined as the level of free amino terminals using the fluorescamine method modified for milk samples (Larsen et al., 2004). Level of free amino terminals was expressed as leucine equivalents (in $\mathrm{m} M$ ) according to a standard curve for leucine.

\section{Genotyping for $\kappa$ - and $\beta-C N$ Genetic Variants}

Blood samples were collected from SRB and SLB and the DNA was genotyped for genetic variants of $\beta$ - and $\kappa$-CN using pyrosequencing, as described by E. Hallén, T. Allmere, J. Näslund, A. Andrén, and A. Lundén, Departments of Food Science and Animal Breeding and Genetics, Swedish Univ. Agric. Sci., Uppsala, Sweden; personal communication).

\section{Cheese Making}

The model cheeses were produced from skimmed milk to reduce the number of variables influencing cheese yield. After $2 \mathrm{~d}$ of cold storage $\left(4^{\circ} \mathrm{C}\right)$, individual milk samples were preheated to $40^{\circ} \mathrm{C}$, defatted, and heated in a pilot plate heating apparatus $\left(72^{\circ} \mathrm{C}\right.$ for $\left.15 \mathrm{~s}\right)$, as described by Allmere et al. (1998). Four liters of skimmed milk was inoculated with a commercial starter culture $(0.1 \mathrm{~g} / \mathrm{L}$ of Lactobacillus helveticus 174 and $0.1 \mathrm{~g} / \mathrm{L}$ of Probat 404, Danisco, Sweden), and incubated at $30^{\circ} \mathrm{C}$ for $30 \mathrm{~min}$. This was followed by addition of chymosin $(1.25 \mathrm{~mL} / \mathrm{L}$ of Chy-Max Plus, 190 International Milk Clotting Units/mL, Christian Hansen A/S, Denmark) and gentle stirring. After $30 \mathrm{~min}$ at $30^{\circ} \mathrm{C}$, the gel formed was cut into 2 -cm cubes. To allow syneresis, the curd was incubated at $50^{\circ} \mathrm{C}$ for another $30 \mathrm{~min}$ during gentle stirring. The whey was removed and the curd was pressed $\left(0.04 \mathrm{~kg} / \mathrm{cm}^{2}\right)$ for $20 \mathrm{~h}$ at room temper- 
ature. After 2 wk of storage at $10^{\circ} \mathrm{C}$, the cheeses were weighed to obtain the yield. To obtain dry weight from individual cheeses, 2 to $3 \mathrm{~g}$ was taken from the interior of the cheeses, grated, and mixed with a fixed amount of sand. Cheese samples were incubated at $105^{\circ} \mathrm{C}$ overnight and then placed in a desiccator for $1 \mathrm{~h}$ before weighing. The cheese yield was expressed in 3 different ways: in relation to amount of cheese milk used (as g of cheese/100 $\mathrm{g}$ of milk or as $\mathrm{g}$ of dry cheese solids/100 $\mathrm{g}$ of milk) or as a transition number (as $\mathrm{g}$ of dry cheese solids/100 g of milk protein), as recommended by Emmons (1993).

\section{Rheological Measurements}

Immediately after rennet addition, a $12-\mathrm{mL}$ sample was transferred to the C25 measuring cup of a Bohlin VOR Rheometer (Malvern Instruments, Nordic AB, Uppsala, Sweden). An oscillating technique was used with a frequency of $1 \mathrm{~Hz}$ and the torsion bar $2 \mathrm{~g} \cdot \mathrm{cm}$. Measurement temperature was $25^{\circ} \mathrm{C}$. The elastic (storage) modulus, $\mathrm{G}^{\prime}$, was determined at a constant strain of 0.0412 and plotted against time to obtain a gelation profile of the curd. Measurements were carried out for $15 \mathrm{~min}$. The milk clotting time (MCT) was recorded as the time in minutes, from chymosin addition to the beginning of curd formation, to compare the clotting rate among the milk samples, and $\mathrm{G}^{\prime}(\mathrm{Pa})$ at $15 \mathrm{~min}\left(\mathrm{G}_{15}^{\prime}\right)$ was recorded to compare curd firmness.

\section{Statistical Analysis}

Multivariate Regression. Partial least square regression analysis (PLS1) was carried out using the software Unscrambler (version 9.0, CAMO ASA, Oslo, Norway). The $\mathrm{x}$-variables consisted of the descriptive variables of breed (SRB, SLB, and SDM), stage of lactation (early, mid, late, and very late), lactation number (1, 2,3 , and 4,) and sample occasion (1, 2, and 3), and the continuous regressors of milk fat, total $\mathrm{CN}$ analyzed, $\kappa$-CN, $\alpha_{\mathrm{S} 1}-\mathrm{CN}, \beta$-CN, $\beta$-LG A, $\beta$-LG B, total $\beta$-LG, $\alpha$ LA, total whey protein analyzed, total protein analyzed (all g/100 g of milk), total CN per total protein analyzed, $\kappa$-CN per total $\mathrm{CN}$ analyzed, $\alpha_{\mathrm{S} 1}-\mathrm{CN}$ per total $\mathrm{CN}$ analyzed, $\beta$-CN per total CN analyzed, $\beta$-LG A per total whey protein analyzed, $\beta$-LG B per total whey protein analyzed, $\alpha$-LA per total whey protein analyzed, lactose $(\mathrm{g} / 100 \mathrm{~g})$, urea $(\mathrm{m} M)$, SCC $(\log / \mathrm{mL})$, free amino terminals ( $\mathrm{m} M$ of leucine), and calcium concentration ( $\mathrm{g} / 100$ g). The response variables (y-variables) analyzed were cheese yield expressed as grams of cheese per one hundred grams of milk, as grams of dry cheese solids per one hundred grams of milk, and as grams of dry cheese solids per one hundred grams of milk protein. Discrimi- nant PLS1 was carried out to compare the milk composition of poorly coagulating and noncoagulating milk with normally coagulating milk (see definitions in first section of Results). Standardized (centered: $\mu=0$, and normalized: $1 / \mathrm{SD}$ ) variables and full cross validation was used.

ANOVA. The GLM procedure from SAS (Version 8e, SAS Institute Inc., Cary, NC) was used to calculate least squares means and standard errors and for pairwise testing of significant differences in concentration of $\kappa$-CN among the genotype classes $\kappa$-CN-AA, $\mathrm{AB}$, and $\mathrm{AE}$. The model contained the fixed effects of $\kappa$ - and $\beta$ $\mathrm{CN}$ genetic variants, breed, sampling, stage of lactation and lactation number. Interactions between main effects were found to be insignificant and therefore were excluded from the statistical model. Concentration of total $\mathrm{CN}$ analyzed was included as covariate in the statistical model to adjust the main effects before ANOVA was accomplished. Significant differences between least squares means were evaluated based on F-values, using the option PDIFF. The GLM procedure was also used to test the overall differences in cheese yield between poorly coagulating and normally coagulating milk. The statistical model used included the fixed effect of coagulation class ( 0 or 1$)$.

\section{RESULTS}

\section{Milk Clotting Properties and Cheese Yield}

The analyzed milk samples were grouped into 4 classes according to their clotting properties; that is, well-coagulating milk, milk with low clotting rate, poorly coagulating milk, and noncoagulating milk (Table 1). Milk samples that started coagulation within 15 min and had firm curd at cutting (30 $\mathrm{min})$ were referred to as well-coagulating milk. Milk samples were assigned to the low clotting rate class if they did not start coagulation within $15 \mathrm{~min}$, but formed a firm curd at cutting. Poorly coagulating milk had a pronounced weaker curd at cutting and a $\mathrm{G}^{\prime}{ }_{15}$ value of less than 15 $\mathrm{Pa}$. Milk that did not start coagulation within $30 \mathrm{~min}$ was referred to as noncoagulating milk. Table 2 shows means and standard errors of cheese yield obtained from poorly coagulating and well-coagulating milk. Average cheese yields were higher for cheeses prepared from normally coagulating than from poorly coagulating milk, irrespective of the cheese yield formula used, but the difference between coagulation groups was not statistically significant (Table 2). Coagulation groups tended to differ significantly, however, when yield was expressed as grams of cheese per one hundred grams of milk $(P=0.055)$. 
Table 1. Classification of the milk samples according to their clotting properties expressed as the milk clotting time (MCT), elastic modulus at $15 \mathrm{~min}\left(\mathrm{G}^{\prime}{ }_{15}\right)$, and curd firmness at $30 \mathrm{~min}$

\begin{tabular}{|c|c|c|c|c|c|}
\hline & MCT & $\mathrm{G}_{15}^{\prime}(\mathrm{Pa})$ & $\begin{array}{l}\text { Curd } \\
\text { firmness } \\
\text { at } 30 \mathrm{~min}^{1}\end{array}$ & $\begin{array}{l}\text { No. of } \\
\text { samples }\end{array}$ & $\begin{array}{l}\text { Percentage } \\
\text { of all } \\
\text { samples }\end{array}$ \\
\hline Well-coagulating milk & $<15$ & $\geq 15$ & Firm & 81 & 61 \\
\hline Milk with low clotting rate & $15-30$ & 0 & Firm & 11 & 8 \\
\hline Poorly coagulating milk & $<30$ & $<15$ & Weak & 38 & 28 \\
\hline \multirow[t]{2}{*}{ Noncoagulating milk } & $>30$ & 0 & No curd & 4 & 3 \\
\hline & & & Total & 134 & 100 \\
\hline
\end{tabular}

${ }^{1}$ Curd firmness at 30 min was evaluated subjectively: firm = firm enough to form cubes; weak = not firm enough to form cubes.

\section{Effects of Analyzed Milk Variables on Milk Clotting Properties and Cheese Yield}

Means and standard deviations of analyzed milk proteins, milk fat (before skimming), calcium, free amino terminals, $\mathrm{pH}, \mathrm{SCC}, \mathrm{G}^{\prime}{ }_{15}$, MCT, and cheese yield are presented in Table 3 and 4 . Results from the PLS1 analyses are presented in Figures 1 and 2. Concentrations of lactose, urea, free amino terminals, $\mathrm{pH}$, and SCC did not significantly affect milk clotting properties or cheese yield and did not improve the multivariate regression model when included. These variables were therefore excluded from the final model. The cheese yield, expressed as grams of cheese per one hundred grams of milk (Figure 1a), was improved at increasing concentrations of milk fat $(P<0.01), \kappa-\mathrm{CN}(P<0.001)$, $\alpha_{\mathrm{S} 1}-\mathrm{CN}(P<0.001), \beta-\mathrm{CN}(P<0.001)$, total $\mathrm{CN}$ analyzed $(P<0.001), \beta$-LG B $(P<0.01)$, total $\beta$-LG $(P<0.001)$, total protein analyzed $(P<0.001)$, and total whey protein analyzed $(P<0.001)$. The same list of variables was also important for the cheese yield when expressed as grams of dry cheese solids per one hundred grams of milk (results not shown). The significant effect of calcium concentration on cheese yield (Figure 1a,b) was very low. Cheese yield, in relation to exploitation of milk protein for cheese making (expressed as $\mathrm{g}$ of dry cheese solids $/ 100 \mathrm{~g}$ of milk protein), was improved at increasing concentrations of $\beta$-LG B $(P<0.001)$, total $\mathrm{CN}$ per total protein analyzed $(P<0.01), \beta$-LG B per total whey protein analyzed $(P<0.001)$, and $\alpha$-LA per total whey protein analyzed $(P<0.01)$. The $\beta$-LG A concentration and the $\beta$-LG A to total whey protein ratio analyzed were negatively associated with grams of dry cheese solids per one hundred grams of milk protein $(P<0.01$ and $P<0.001$, respectively). Cheese yield, expressed as grams of cheese per one hundred grams of milk (Figure 1a), was further positively associated with late lactation $(P<0.01)$ and lactation number $1(P<0.05)$, but negatively associated with early lactation $(P<0.01)$ and lactation number $4(P<0.01)$. Cheese yield was also positively associated with sampling occasion number 1 (in September; Figure 1a). No significant differences in cheese yield or milk clotting properties between the investigated breeds of SRB, SLB, and SDM were observed. Poorly coagulating and noncoagulating milk was associated with lower concentration of $\kappa$-CN $(P<0.001)$ and $\kappa$-CN per total $\mathrm{CN}$ analyzed $(P<0.001$; Figure 2). Poorly coagulating and noncoagulating milk were most frequent within lactation number $1(P<$ $0.05)$.

The PLS1 model explained less than $50 \%$ of the total variation in milk clotting properties (Figure 2) and in cheese yield expressed as grams of dry cheese solids per one hundred grams of milk protein (Figure 1b). This was indicated by the correlation coefficient $\left(R^{2}\right)$ between measured and predicted y-variables, which were less than 0.50 (Figure $1 \mathrm{~b}$ and 2). A larger amount of the total variation could be explained by the model when describing variations in cheese yield expressed as

Table 2. Cheese yield (expressed in 3 ways) obtained from poorly coagulating and well-coagulating milk samples

\begin{tabular}{|c|c|c|c|}
\hline & $\begin{array}{l}\text { g of cheese/ } \\
100 \mathrm{~g} \text { of milk }\end{array}$ & $\begin{array}{l}\mathrm{g} \text { of dry cheese } \\
\text { solids/100 } \mathrm{g} \\
\text { of milk }\end{array}$ & $\begin{array}{l}\mathrm{g} \text { of dry cheese } \\
\text { solids } / 100 \mathrm{~g} \\
\text { of milk protein }\end{array}$ \\
\hline Poorly coagulating milk $(\mathrm{n}=38)$ & $7.69 \pm 0.19$ & $3.03 \pm 0.07$ & $92.44 \pm 1.61$ \\
\hline Well-coagulating milk $(\mathrm{n}=81)$ & $8.14 \pm 0.13$ & $3.17 \pm 0.05$ & $93.20 \pm 1.14$ \\
\hline Degrees of freedom & 1 & 1 & 1 \\
\hline$P$-value & 0.055 & 0.139 & 0.682 \\
\hline
\end{tabular}


Table 3. Means and SD of analyzed milk proteins, ${ }^{1}$ milk fat, lactose, urea, calcium, $\mathrm{pH}$, free amino terminals, and SCC

\begin{tabular}{|c|c|c|c|c|c|}
\hline & Mean & $\mathrm{SD}$ & $\mathrm{df}$ & Minimum & Maximum \\
\hline Total protein analyzed ${ }^{2}$ & 3.39 & 0.34 & 133 & 2.40 & 4.44 \\
\hline Total CN analyzed ${ }^{3}$ & 2.73 & 0.39 & 133 & 1.83 & 3.74 \\
\hline CN/total protein analyzed ${ }^{4}$ & 0.81 & 0.03 & 133 & 0.73 & 0.89 \\
\hline$\alpha_{\mathrm{S} 1}-\mathrm{CN}$ & 1.05 & 0.17 & 133 & 0.66 & 1.42 \\
\hline$\beta-\mathrm{CN}$ & 1.25 & 0.21 & 133 & 0.77 & 1.73 \\
\hline$\kappa-\mathrm{CN}$ & 0.44 & 0.10 & 133 & 0.20 & 0.71 \\
\hline$\kappa-\mathrm{CN} /$ total $\mathrm{CN}$ analyzed & 0.16 & 0.03 & 133 & 0.09 & 0.23 \\
\hline$\alpha_{\mathrm{S} 1}-\mathrm{CN} /$ total $\mathrm{CN}$ analyzed & 0.38 & 0.03 & 133 & 0.26 & 0.44 \\
\hline$\beta$-CN/total CN analyzed & 0.46 & 0.03 & 133 & 0.37 & 0.55 \\
\hline Total whey proteins analyzed $^{5}$ & 0.62 & 0.14 & 133 & 0.36 & 0.97 \\
\hline$\beta$-LG A & 0.29 & 0.23 & 133 & $0.00^{6}$ & 0.82 \\
\hline$\beta$-LG B & 0.25 & 0.14 & 133 & $0.00^{7}$ & 0.66 \\
\hline Total $\beta$-LG & 0.54 & 0.13 & 133 & 0.28 & 0.89 \\
\hline$\alpha$-LA & 0.08 & 0.02 & 133 & 0.05 & 0.15 \\
\hline$\beta$-LG B/total whey proteins analyzed & 0.44 & 0.29 & 133 & $0.00^{6}$ & 0.91 \\
\hline$\beta$-LG A/total whey proteins analyzed & 0.42 & 0.31 & 133 & $0.00^{7}$ & 0.92 \\
\hline$\alpha$-LA/total whey proteins analyzed & 0.14 & 0.04 & 133 & 0.08 & 0.26 \\
\hline Milk fat (g/100 g of milk) & 4.92 & 0.93 & 133 & 3.08 & 8.30 \\
\hline Lactose (g/100 g of milk) & 4.78 & 0.23 & $127^{8}$ & 4.16 & 5.31 \\
\hline Urea $(\mathrm{m} M)$ & 4.96 & 1.45 & 127 & 1.67 & 9.12 \\
\hline Calcium (g/100 g of milk) & 0.12 & 0.01 & $131^{8}$ & 0.09 & 0.16 \\
\hline $\mathrm{pH}$ & 6.70 & 0.06 & 133 & 6.55 & 6.84 \\
\hline Free amino terminals ( $\mathrm{m} M$ of leucine) & 1.01 & 0.26 & 133 & 0.57 & 1.79 \\
\hline $\mathrm{SCC}(\log / \mathrm{mL})$ & 4.99 & 0.37 & $126^{8}$ & 4.30 & 6.00 \\
\hline
\end{tabular}

${ }^{1}$ Concentration $(\mathrm{g} / 100 \mathrm{~g}$ of milk), in relation to total $\mathrm{CN}$ analyzed or total whey proteins analyzed.

${ }^{2}$ Concentration (g/100 g of milk) of $\alpha_{\mathrm{S} 1}-\mathrm{CN}, \beta-\mathrm{CN}, \kappa-\mathrm{CN}, \beta-\mathrm{LG}$, and $\alpha$-LA determined by reverse phase (RP)-HPLC.

${ }^{3}$ Concentration (g/100 g of milk) of $\alpha_{\mathrm{S} 1}-\mathrm{CN}, \beta$-CN, and $\kappa$-CN determined by RP-HPLC.

${ }^{4}$ The $\mathrm{CN}$ to total protein ratio determined from the RP-HPLC analysis.

${ }^{5}$ Concentration (g/100g milk) of $\beta$-LG and $\alpha$-LA determined by RP-HPLC.

${ }^{6}$ Milk samples that lack the A-variant of $\beta$-LG.

${ }^{7}$ Milk samples that lack the B-variant of $\beta$-LG.

${ }^{8}$ Number of observations reduced due to missing data.

grams of cheese per one hundred grams of milk with $\mathrm{R}^{2}=0.65$ (Figure 1a).

\section{Influence of $\kappa-\mathrm{CN}$ Genotype on $\kappa-\mathrm{CN}$ Concentration and Milk Clotting Properties}

Table 5 shows least squares means and standard errors of concentration of $\kappa$-CN in milk from SRB and
SLB cows with the $\kappa$-CN AA, $\mathrm{AB}$, and $\mathrm{AE}$ genotypes. Concentration of $\kappa$-CN was significantly higher in milk with the $\mathrm{AB}$ genotype compared with milk with the $\mathrm{AA}$ genotype $(P<0.05)$. No difference in $\kappa$-CN concentration was found between the $\mathrm{AB}$ and $\mathrm{AE}$ genotypes or between the AA and AE genotypes. Furthermore, no effect of $\beta$-CN genotype on $\kappa$-CN concentration was found. Comparing poorly and noncoagulating milk with well-

Table 4. Means and SD of milk clotting time (MCT) and elastic modulus at $15 \min \left(\mathrm{G}_{15}^{\prime}\right)$, and cheese yield

\begin{tabular}{lrrrrr}
\hline & Mean & \multicolumn{1}{c}{ SD } & df & Minimum & Maximum \\
\hline $\begin{array}{l}\text { Milk clotting properties } \\
\text { MCT (min) }\end{array}$ & 4.81 & 2.23 & $107^{1}$ & 0.8 & 10.8 \\
$\quad$ G $_{15}^{(\mathrm{Pa})}$ & 42.04 & 41.05 & $112^{1}$ & 1 & 225 \\
Cheese yield & & & & & \\
g of cheese/100 g of milk & 8.00 & 1.13 & $124^{2}$ & 5.20 & 10.80 \\
g of dry cheese solid/100 g of milk & 3.12 & 0.43 & $114^{2}$ & 2.10 & 4.20 \\
g of dry cheese solid/100 g of milk protein & 92.81 & 9.26 & $114^{2}$ & 58.06 & 129.68 \\
\hline
\end{tabular}

\footnotetext{
${ }^{1}$ Number of observations reduced due to milk samples that did not start coagulation within 15 min and to missing data.

${ }^{2}$ Number of observations was reduced due to noncoagulating milk (i.e., cheese yield was equal to zero) and due to missing data.
} 
$\mathrm{Y}=\mathrm{g}$ of cheese per $100 \mathrm{~g}$ of milk

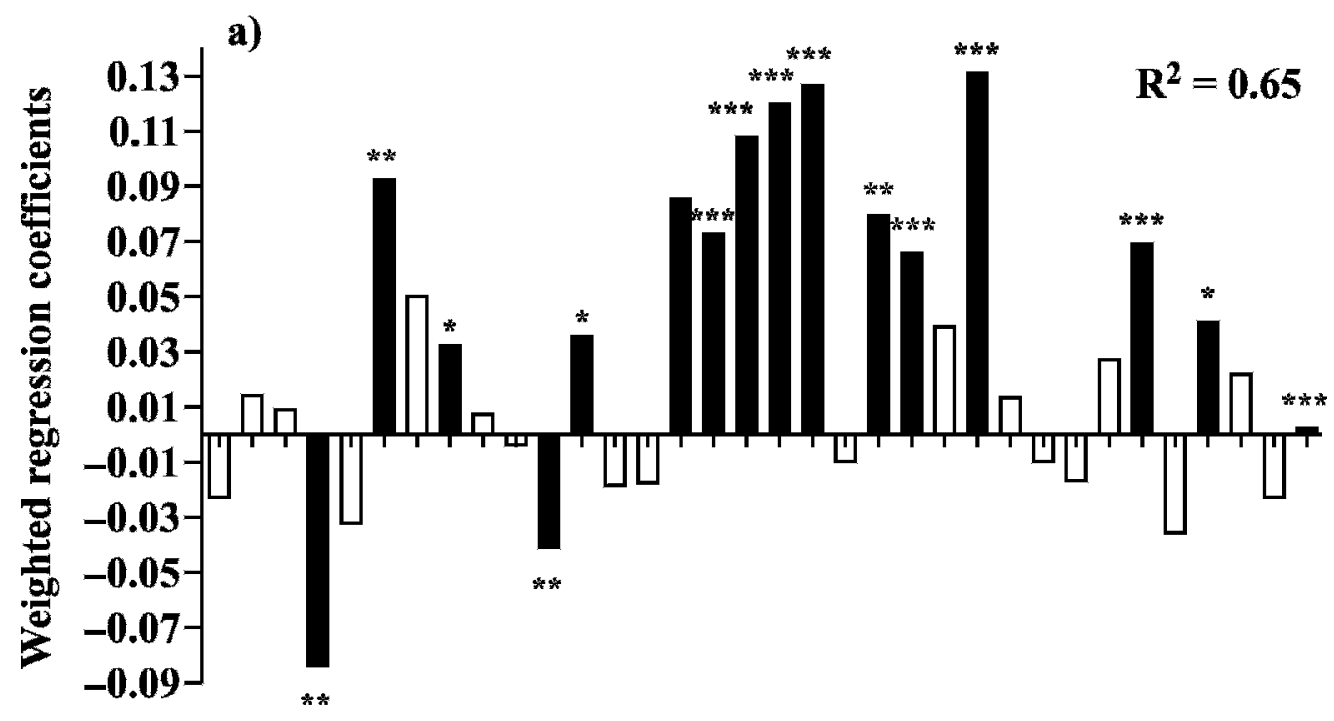

x-values

$\mathrm{Y}=\mathrm{g}$ of dry cheese solids per $100 \mathrm{~g}$ of milk protein

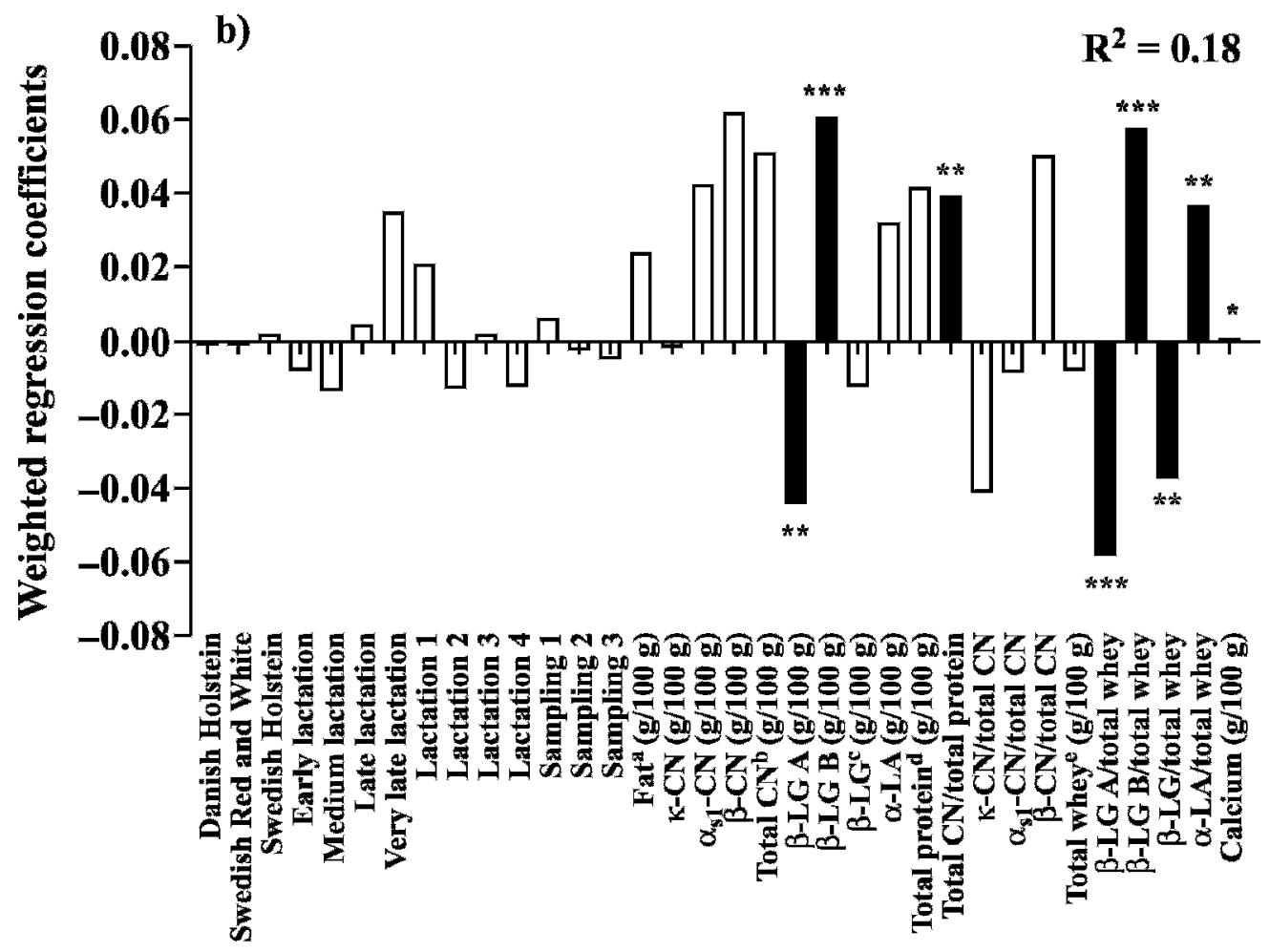

x-values

Figure 1. Results from the partial least squares regression analysis presented as the weighted regressions between x-variables of analyzed milk proteins (determined by HPLC), milk fat, calcium, breed, stage of lactation, lactation number, and sampling occasion, and the yvariables $\mathrm{g}$ of cheese/100 $\mathrm{g}$ of milk (panel a) and $\mathrm{g}$ of dry cheese solids/100 $\mathrm{g}$ of milk protein (panel b). Black bars represent significant regression coefficients. $\mathrm{R}^{2}$ is the correlation coefficient between measured and predicted y variables. All y-variables followed normal distributions. ${ }^{\mathrm{a}} \mathrm{Milk}$

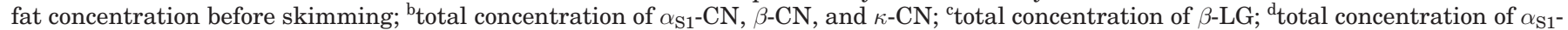

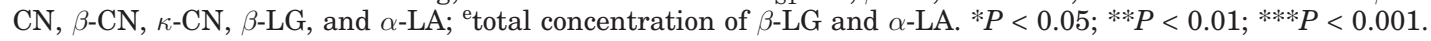




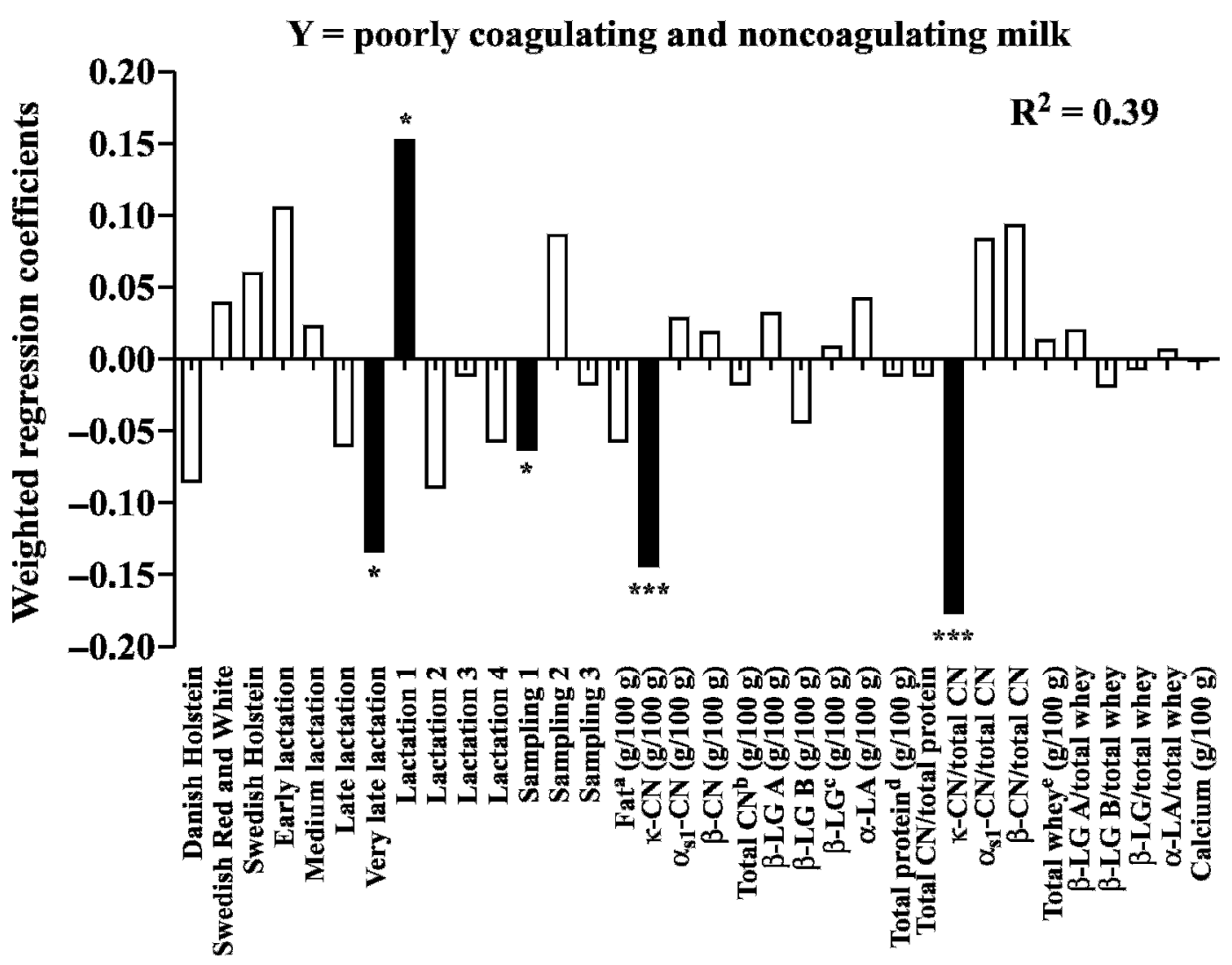

values

Figure 2. Results from the discriminant partial least squares regression analysis presented as weighted regressions between $x$-variables of analyzed milk proteins (determined by HPLC), milk fat, calcium, breed, stage of lactation, lactation number, and sampling occasion, and the $\mathrm{y}$-variable of poorly coagulating and noncoagulating milk. $\mathrm{R}^{2}$ is the correlation coefficient between measured and predicted $\mathrm{y}$-variables. The number of observations in the poorly coagulating and noncoagulating group was 42 , whereas in the normally coagulating group, it was 81. ${ }^{a}$ Milk fat concentration before skimming; ${ }^{b}$ total concentration of $\alpha_{\mathrm{S} 1}-\mathrm{CN}, \beta$-CN, and $\kappa$-CN; ${ }^{\mathrm{c}}$ total concentration of $\beta$-LG; ${ }^{\mathrm{d}}$ total concentration of $\alpha_{\mathrm{S1}}-\mathrm{CN}, \beta$-CN, $\kappa$-CN, $\beta$-LG, and $\alpha$-LA; ${ }^{\text {total }}$ concentration of $\beta$-LG and $\alpha$-LA. $* P<0.05 ; * * P<0.01 ; * * * P<0.001$.

coagulating milk, the $\mathrm{AE}$ genotype was more frequent within the poorly and noncoagulating group (Table 5).

\section{DISCUSSION}

The results from this investigation showed the effect of variations in the milk protein composition, from individual cows, on milk clotting properties and yield of model cheeses. Studies on variation in cheese yielding capacity in relation to milk composition from a substantial number of individual milk samples are rare $(\mathrm{Ng}$ Kwai-Hang et al., 1989), whereas studies on cheeses produced from pooled milk samples are more frequent (Mayer et al., 1997; Ikonen et al., 1999b; Auldist et al., 2004). There are also few reports on milk clotting properties recorded on a rheometer (Sbodio et al., 1997) because it has been more common to use a formagraph (Aleandri et al., 1989; Ikonen et al., 1999b; Auldist et al., 2004).
It has been shown that milk with impaired clotting properties was not improved by mixing it with an equal amount of well-coagulating milk (Okigbo et al., 1985b). The same authors showed that the milk clotting properties of poorly coagulating milk were improved by addition of calcium chloride and by reduction of milk $\mathrm{pH}$. However, the clotting properties were not improved to the same level as in well-coagulating milk. The association we found between poorly coagulating milk and lactation number 1 (Figure 2) is in line with the results of Schaar (1984). He observed that milk samples from cows within lactation number 1 and 2 formed weaker curds than milk from cows in later lactations and suggested that this effect could be due to differences in composition and distribution of milk salts.

We found that the $\kappa$-CN concentration and its proportion in relation to $\alpha_{\mathrm{S} 1}-\mathrm{CN}$ and $\beta$-CN were significantly lower in poorly coagulating and noncoagulating milk. This finding is in line with the results of St-Gelais and 
Haché (2005), who showed poorer milk clotting properties of milk enriched with $\beta$-CN powder. They also found that cheeses produced from $\beta$-CN enriched milk were harder. The higher $\kappa$-CN concentration found in milk from cows with the $\kappa$-CN $\mathrm{AB}$ genotype compared with the AA genotype (McLean et al., 1984; van den Berg et al., 1992; Bobe et al., 1999; Table 5) and the positive association between $\kappa$-CN concentration and well-coagulating milk indicate that the $\mathrm{AB}$ genotype can influence milk clotting properties, indirectly, via the $\kappa$-CN concentration. However, the higher frequency of $\kappa$-CN $\mathrm{AE}$ in poorly and noncoagulating milk (Table 5) suggests that functionalities of $\kappa$-CN, other than solely the concentration, can contribute to the milk clotting properties. The high frequency of $\kappa$ - $\mathrm{CN} \mathrm{AE}$ observed in poorly coagulating milk (Table 5) also supports the significant correlation between the $\kappa$-CN E allele and poor milk clotting ability reported by Ikonen et al. (1999a).

Noncoagulating milk has been observed in several milk clotting studies (Okigbo et al., 1985a; Ikonen et al., 1999a; Nsofor, 2000). It has been suggested that noncoagulating milk could be due to genetic parameters because high heritability estimates for milk clotting properties have been observed (Ikonen et al., 1999a). We found that the average calcium concentration among noncoagulating milk samples was $0.10 \mathrm{~g} / 100 \mathrm{~g}$ of milk (results not shown); that is, below the average of all analyzed milk samples $(0.12 \mathrm{~g} / 100 \mathrm{~g}$; Table 3$)$. It is thus possible that the lower calcium concentration in combination with a low concentration of $\kappa$-CN (Figure 2) was responsible for the noncoagulating milk samples in this study. However, only 4 noncoagulating milk samples were observed (Table 1), which is not enough observations for a statistical evaluation. Hence, it would be interesting to evaluate milk composition in a substantial number of noncoagulating milk samples.

According to the literature, associations between milk clotting properties and cheese yield vary. Aleandri et al. (1989) and Martin et al. (1997) suggested that a firm curd at cutting was associated with high cheese yield, whereas Ikonen et al. (1999b) did not find a significant difference in yield between cheeses made from poorly coagulating and well-coagulating milk. RiddellLawrence and Hicks (1989) reported that curd-healing time affected cheese yield more than coagulum strength at cutting. However, it has also been suggested that curd firmness at cutting is important for the sensory attributes of cheeses. Johnson et al. (2001) reported that an increase in cheese moisture content, due to firmer curd at cutting, resulted in softer and smoother texture of reduced-fat Cheddar cheeses. In the present study, the difference (although not significant) in cheese yield between the poorly coagulating and the well-coag- 
ulating milk was more pronounced when expressing yield as grams of cheese per one hundred grams of milk than as grams of dry cheese solids per one hundred grams of milk (Table 2). This suggests that an increase in cheese yield due to a firmer curd at cutting could be associated with an increase in the water-holding capacity of cheeses prepared from well-coagulating milk, as reported by Johnson et al. (2001).

The significantly positive correlation between $\beta$-LG $\mathrm{B}$ and cheese yield (Figure 1) was expected because it has been suggested that the B allele correlates with higher CN number (Schaar, 1984; van den Berg et al., 1992; Lunden et al., 1997) because of the lower concentration of $\beta$-LG in this milk (McLean et al., 1984; NgKwai-Hang et al., 1987; Graml et al., 1989). In our study, the CN to total protein ratio analyzed did not affect the cheese yield expressed as grams of cheese per one hundred grams of milk (Figure 1a), whereas the yield expressed as grams of dry cheese solids per one hundred grams of milk protein was affected (Figure 1b). The latter expression would thus be the best to explain the effect of $\mathrm{CN}$ to total protein ratio analyzed on cheese making properties of milk. The milk fat was important for the cheese yield even though the milk was defatted before cheese making. This was probably indirectly due to the strong significant correlation $(P<$ 0.001 ; results not shown) between concentration of total protein and milk fat.

The small amount (less than 50\%) of the total variation in milk clotting properties (Figure 2) and grams of dry cheese solids per one hundred grams of milk protein (Figure 1b) explained by milk protein composition implies that other variables not measured in our study contributed significantly to these traits. Auldist et al. (2004) evaluated the effect of milk composition on milk clotting properties from Friesian and Jersey dairy cows. They also found that milk protein composition only partly explained the total variation in milk clotting properties. However, the process from milk to cheese is very complex with several significant variables, which makes it difficult to find only one or a few markers for the cheese-making properties.

\section{CONCLUSIONS}

A surprisingly large fraction of the individual milk samples analyzed had poor clotting properties (about $30 \%$ ), with a tendency of impaired cheese yield. A low concentration of $\kappa$-CN and a low proportion of $\kappa$-CN in relation to total $\mathrm{CN}$ analyzed were associated with poorly coagulating and noncoagulating milk. However, the analyzed milk protein composition only partly explained the total variation in milk clotting properties. Nevertheless, our results suggest that milk superior for cheese making is high in concentrations of $\alpha_{\mathrm{S1}^{-}}, \beta-$, and $\kappa$ - $\mathrm{CN}$, has high $\kappa$ - $\mathrm{CN}$ in relation to total $\mathrm{CN}$, and contains $\beta$-LG B. Furthermore, a high concentration of $\mathrm{CN}$ to total protein analyzed was significant for the transfer of proteins from milk to cheese.

\section{ACKNOWLEDGMENTS}

The authors wish to thank PhD student Jessica Näslund, Department of Animal Breeding and Genetics, Swedish University of Agricultural Sciences for genotyping the genetic variants of $\beta$ - and $\kappa-\mathrm{CN}$. At the same university, Toomas Allmere, Department of Food Sciences, is acknowledged for planning and supervision of this project, and Roger Andersson, Department of Food Sciences, for good advice regarding the statistical analyses. Gudrun Franzén and Lena Hagenvall are acknowledged for the milk sample collection. At the Danish Institute of Agricultural Sciences, Hanne Damgaard Poulsen, Department of Animal Health, Welfare and Nutrition is acknowledged for performing the calcium analyses and Stina Greis Handberg and Helle Louise Christensen, Department of Food Quality, for excellent technical assistance. The Chy-Max Plus was a kind gift from Marianne Harboe, Christian Hansen A/S, Denmark. The financial support from the Swedish Farmers' Foundation for Agricultural Research, Danish Dairy Research Foundation, and the Innovation Law is gratefully acknowledged.

\section{REFERENCES}

Aleandri, R., J. S. Schneider, and L. G. Buttazzoni. 1989. Evaluation of milk for cheese production based on milk characteristics and formagraph measures. J. Dairy Sci. 72:1967-1989.

Allmere, T., A. Andrén, A. Lunden, and L. Björck. 1998. Interactions in heated skim milk between genetic variants of $\beta$-lactoglobulin and $\kappa$-casein. J. Agric. Food Chem. 46:3004-3008.

Auldist, M. J., K. A. Johnston, N. J. White, W. P. Fitzsimons, and M. J. Boland. 2004. A comparison of the composition, coagulation characteristics and cheese making capacity of milk from Friesian and Jersey dairy cows. J. Dairy Res. 71:51-57.

Auldist, M., C. Mullins, B. O'Brien, B. T. O'Kennedy, and T. Guinee. 2002. Effect of cow breed on milk coagulation properties. Milchwissenschaft 57:140-143.

Bobe, G., D. C. Beitz, A. E. Freeman, and G. L. Lindberg. 1999. Effect of milk protein genotypes on milk protein composition and its genetic parameter estimates. J. Dairy Sci. 82:2797-2804.

Bordin, G., F. C. Raposo, B. Calle, and A. R. Rodriguez. 2001. Identification and quantification of major bovine milk proteins by liquid chromatography. J. Chromatogr. A. 928:63-76.

Caroli, A., P. Bolla, E. Budelli, G. Barbieri, and P. Leone. 2000. Effect of $\kappa$-casein E allele on clotting aptitude of Italian Friesian milk. Zootec. Nutr. Anim. 26:127-130.

Chiofalo, V., R. Maldonato, B. Martin, D. Dupont, and J. B. Coulon. 2000. Chemical composition and coagulation properties of Modicana and Holstein cows' milk. Ann. Zootech. 49:497-503.

Emmons, D. B. 1993. Definition and expression of cheese yield. Pages 12-20 in Factors Affecting the Yield of Cheese. D. B. Emmons, ed. International Dairy Federation, Brussels, Belgium.

Graml, R., G. Weiss, J. Buchberger, and F. Pirchner. 1989. Different rates of synthesis of whey-protein and casein by alleles of the 
$\beta$-lactoglobulin and $\alpha_{\mathrm{S} 1}$-casein locus in cattle. Genet. Sel. Evol. 21:547-554.

Ikonen, T., K. Ahlfors, R. Kempe, M. Ojala, and O. Ruottinen. 1999a. Genetic parameters for the milk coagulation properties and prevalence of non-coagulating milk in Finnish dairy cows. J. Dairy Sci. 82:205-214.

Ikonen, T., O. Ruottinen, E. L. Syvaoja, K. Saarinen, E. Pahkala, and M. Ojala. 1999b. Effect of milk coagulation properties of herd bulk milks on yield and composition of Emmental cheese. Agric. Food Sci. Finland 8:411-422.

Johnson, M. E., C. M. J. Chen, and J. J. Jaeggi. 2001. Effect of rennet coagulation time on composition, yield and quality of reduced-fat Cheddar cheese. J. Dairy Sci. 84:1027-1033.

Larsen, L. B., M. D. Rasmussen, M. Bjerring, and J. H. Nielsen. 2004. Proteases and protein degradation in milk from cows infected with Streptococcus uberis. Int. Dairy J. 14:899-907.

Lindmark-Månsson, H., R. Fonden, and H. E. Pettersson. 2003. Composition of Swedish dairy milk. Int. Dairy J. 13:409-425.

Lunden, A., M. Nilsson, and L. Janson. 1997. Marked effect of $\beta$ lactoglobulin polymorphism on the ratio of casein to total protein in milk. J. Dairy Sci. 80:2996-3005.

Macheboeuf, D., J. B. Coulon, and P. D'Hour. 1993. Effect of breed, protein genetic variants and feeding on cows' milk coagulation properties. J. Dairy Res. 60:43-54.

Martin, B., J. F. Chamba, J. B. Coulon, and E. Perreard. 1997. Effect of milk chemical composition and clotting characteristics on chemical and sensory properties of Reblochon de Savoie cheese. J. Dairy Res. 64:157-162.

Mayer, H. K., M. Ortner, E. Tschager, and W. Ginzinger. 1997. Composite milk protein phenotypes in relation to composition and cheese making properties of milk. Int. Dairy J. 7:305-310.

McLean, D. M., E. R. Bruce Graham, and R. W. Ponzoni. 1984. Effects of milk protein genetic variants on milk yield and composition. J. Dairy Res. 51:531-546.

Najera, A. I., M. de Renobales, and L. J. R. Barron. 2003. Effects of pH, temperature, $\mathrm{CaCl} 2$ and enzyme concentrations on the rennetclotting properties of milk: A multifactorial study. Food Chem. 80:345-352.

Ng-Kwai-Hang, K. F. 1998. Genetic polymorphism of milk proteins: Relationships with production traits, milk composition and technological properties. Can. J. Anim. Sci. 78:131-147.

Ng-Kwai-Hang, K. F., J. F. Hayes, and J. E. Moxley. 1987. Variation in milk protein concentrations associated with genetic polymorphism and environmental factors. J. Dairy Sci. 70:563-570.

Ng-Kwai-Hang, K. F., I. Politis, I. R. Cue, and A. S. Marziali. 1989. Correlations between coagulation properties of milk and cheese yielding capacity and cheese composition. Can. Inst. Food Sci. Technol. J. 22:291-294.

Nsofor, L. M. 2000. Curd-forming casein concentration in poor/nonchymosin coagulating milk from individual cows. J. Food Sci. Technol. 37:153-157.
O’Brien, B., R. Mehra, J. F. Connolly, and D. Harrington. 1999. Seasonal variation in the composition of Irish manufacturing and retail milks 1 . Chemical composition and renneting properties. Irish J. Agric. Food Res. 38:53-64.

Okigbo, L. M., G. H. Richardson, R. J. Brown, and C. A. Ernstrom. 1985a. Casein composition of cow's milk of different chymosin coagulation properties. J. Dairy Sci. 68:1887-1892.

Okigbo, L. M., G. H. Richardson, R. J. Brown, and C. A. Ernstrom. 1985b. Effects of $\mathrm{pH}$, calcium chloride and chymosin concentration on coagulation properties of abnormal and normal milk. J. Dairy Sci. 68:2527-2533.

Okigbo, L. M., G. H. Richardson, R. J. Brown, and C. A. Ernstrom. 1985c. Variation in coagulation properties of milk from individual cows. J. Dairy Sci. 68:822-828.

Ostersen, S., J. Foldager, and J. E. Hermansen. 1997. Effects of stage of lactation, milk protein genotype and body condition at calving on protein composition and renneting properties of bovine milk. J. Dairy Res. 64:207-219.

Riddell-Lawrence, S., and C. L. Hicks. 1989. Effect of curd firmness on stirred curd cheese yield. J. Dairy Sci. 72:313-321.

Sbodio, O. A., E. J. Tercero, V. R. Coutaz, J. A. Luna, and E. Martinez. 1997. Simultaneous interaction of $\mathrm{pH}, \mathrm{CaCl}_{2}$ addition, temperature and enzyme concentration on milk coagulation properties. Food Sci. Technol. Int. 3:291-298.

Schaar, J. 1984. Effects of $\kappa$-casein genetic variants and lactation number on the renneting properties of individual milks. J. Dairy Res. 51:397-406.

Schaar, J., B. Hansson, and H. E. Pettersson. 1985. Effects of genetic variants of $\kappa$-casein and $\beta$-lactoglobulin on cheesemaking. J. Dairy Res. 52:429-437.

St-Gelais, D., and S. Haché. 2005. Effect of $\beta$-casein concentration in cheese milk on rennet coagulation properties, cheese composition and cheese ripening. Food Res. Int. 38:523-531.

Storry, E. J., A. S. Grandison, D. Millard, A. J. Owen, and G. D. Ford. 1983. Chemical composition and coagulating properties of renneted milks from different breeds and species of ruminant. J. Dairy Res. 50:215-229.

van den Berg, G., J. T. M. Escher, P. J. de Koning, and H. Bovenhuis. 1992. Genetic polymorphism of $\kappa$-casein and $\beta$-lactoglobulin in relation to milk composition and processing properties. Neth. Milk Dairy J. 46:145-168.

Verdier-Metz, I., J. B. Coulon, P. Pradel, C. Viallon, and J. L. Berdague. 1998. Effect of forage conservation (hay or silage) and cow breed on the coagulation properties of milks and on the characteristics of ripened cheeses. J. Dairy Res. 65:9-21.

Wedholm, A., E. Hallén, L. B. Larsen, H. Lindmark-Månsson, A. H. Karlsson, and T. Allmere. 2006. Comparison of milk protein composition in a Swedish and a Danish dairy herd using reversedphase HPLC. Acta Agric. Scand., A. Anim. Sci. (accepted) 